Kwartalnik Historyczny

Vol. CXXVIII, 2021

Eng.-Language Edition no. 5, pp. 79-104

PL ISSN 0023-5903

MIKOŁAJ GETKA-KENIG

https://orcid.org/0000-0002-1180-064X

Institute for the History of Science, Polish Academy of Sciences, Warsaw

\title{
USURPATION OF ARISTOCRATIC PRIVILEGE AND THE SOCIAL IDENTITY OF THE POLISH NOBLE ELITE IN THE PERIOD OF THE PARTITIONS
}

Abstract: The aristocratic titles, which the partitioning monarchies granted to some of their Polish noble subjects in the long nineteenth century, did not play a decisive role in the development and formation of the modern Polish noble elite. The foreign titles could only sanction the internal noble hierarchy, which was apparently much more determined by specific noble traditions and the cult of the pre-partition past. This argument is evidenced by the cases of families which did not need formal title grants to be recognized as truly aristocratic in that period.

Keyw ords: aristocracy, hereditary titles, nobility, social hierarchy, elite.

For the civil community of the nobility (szlachta), the fall of the Polish-Lithuanian Commonwealth towards the end of the eighteenth century was not just of a strictly political or legal nature, but also of social significance. All the partitioning powers - Russia, Prussia and Austria - had feudal traditions as well as legally and culturally distinct groups which were analogous to the Polish bene nati (dvoryanstvo in Russia, adel in Prussia and Austria). Yet despite all the similarities, the differences were quite substantial. Even if we take into account that in this respect there were also differences between the partitioning powers themselves, the status of nobles in the Commonwealth was still unique by comparison. It was based on their highly privileged position within the political system, characteristic of the republican model and alien to the partitioners. A particularly drastic difference concerned the dominant position of the Polish-Lithuanian nobility in its relations with their monarchs, in the Commonwealth elected for life by nobles themselves since the fourteenth century (originally, until the mid-sixteenth century from among members of the Jagiellonian dynasty, and later regardless of their family membership). This meant that 
as a result of the so-called free election a nobleman could become king, which indeed happened on four occasions. Moreover, in the pre-partition tradition the monarch could not freely exercise the right of ennoblement, as each noble promotion had to be approved by the parliament, that is by the representatives of the nobility. On the other hand, in the partitioning monarchies the status of those of noble birth was, in fact, that of subjects, and their political subjectivity as an estate was very limited, even if they had some privileges, including forms of estate representation. ${ }^{1}$

There was also a marked difference in the very structure of the nobility as an estate, which in Poland, unlike the situation in the partitioning empires, was formally homogenous. It is true that the old Polish tradition respected senators as a distinctly prestigious social group; senators were ministers, voivodes and castellans sitting in the Senate and appointed by the king (in 1776-88 by the Permanent Council presided over by the king), who were treated as 'older brothers' of other nobles. Although only ministers - the least numerous group among them - had specific powers, all the members of the Senate played an important political role: that of liaising between the monarch and the nobility (represented by the Chamber of Deputies). However, the privilege of having a seat in the Senate was granted only for life, and it was not hereditary. Formally any nobleman could, if a vacancy occurred, take up either the less respected senatorial 'bench' (or a place without a chair, earmarked for the so-called minor or district castellans), or a 'chair' (for major castellans, voivodes and ministers). ${ }^{2}$ The symbolic division into two classes of senators was in practice abolished only in 1775, when all members of the chamber were granted an equal right to being addressed as 'honourable' (a title reserved until that point solely for voivodes and major cas-

${ }^{1}$ See Jerzy Jedlicki, 'Szlachta', in Przemiany społeczne w Królestwie Polskim 1815-1864, ed. Witold Kula and Janina Leskiewiczowa, Wrocław, 1979, pp. 27-56 (p. 29); Andrzej Zajączkowski, Szlachta polska: Kultura i struktura, Warsaw, 1993, pp. 99-100, 102-03; Jerzy Lukowski, The European Nobility in the Eighteenth Century, Basingstoke, 2003, pp. 20, 41-42; Iryna Vushko, The Politics of Cultural Retreat: Imperial Bureaucracy in Austrian Galicia, 1772-1867, New Haven, 2015, pp.128-35. For more on the general specificity of the Polish nobility, see also Robert I. Frost, 'The Nobility of Poland-Lithuania, 1569-1795', in The European Nobilities in the Seventeenth and Eighteenth Centuries, 2 vols, ed. Hamish M. Scott, Basingstoke and New York, 2007, vol. 2, pp. 266-310.

${ }^{2}$ Teresa Zielińska, Magnateria polska epoki saskiej: Funkcje urzędów i królewszczyzn $w$ procesie przeobrażeń warstwy szlacheckiej, Wrocław, 1977, p. 42; Jerzy Lukowski, Liberty's Folly: The Polish-Lithuanian Commonwealth in the Eighteenth Century, 1697-1795, London, 1991, pp. 16, 107; Frost, 'The Nobility of Poland-Lithuania', p. 289. Apart from senatorial positions noblemen also highly appreciated the so-called dignities which evolved from old court offices. 
tellans). ${ }^{3}$ As Adam Amilkar Kosiński, a Warsaw genealogist, rightly put it in the second half of the nineteenth century, "in this country of the equality of the nobility [...] the only mark of family distinction was the number and quality [that is rank] of senators a family produced - there are so few exceptions that they do not distort the rule'. ${ }^{4}$

It is true that the passing of positions in the Senate from father to son, or at least within one patrolinear family, was a well-established practice in the eighteenth century. In the first half of that century - a period thoroughly explored in this respect in historiography - descendants of senators constituted a majority (of about 60 per cent) among voivodes and major castellans. ${ }^{5}$ This was the group from which were drawn the so-called magnates (magnaci), that is the wealthiest noblemen (their wealth was based not only on private property, but to a large extent also on leases of the Crown lands (królewszczyzny), the most profitable of which went mainly to senators). ${ }^{6}$ However, the instances of 'inheriting' seats in the Senate never products of a legal privilege, but of the current political situation (the current interests and local alliances of the king). Depending on the specific circumstances, senatorial promotion could result from being either a member of a senatorial family or a homo novus. ${ }^{7}$ New candidates for the Senate were promoted particularly by King Stanisław August, the enlightened reformer from the second half of the eighteenth century. He sought in this way to build his own party in opposition to the old elite of the nobility. ${ }^{8}$ In any case, his actions in creating a new noble elite had far-reaching consequences: many families promoted by him were able not only to maintain but also to consolidate their social position after the partitions, in the post-Commonwealth socio-political circumstances. ${ }^{9}$

Significantly, while under the reform of the state - of which the king was patron and which was expressed primarily in the Constitution of 3 May 1791 - landless noblemen were to be deprived of their political rights, the principle of equality of the landed nobility before the law remained

${ }^{3}$ Zdzisław Kaczmarczyk, 'Kasztelanowie konarscy: Studium z historii urzędów ziemskich i nadwornych', CPH, 2, 1949, pp. 1-23 (p. 5).

${ }^{4}$ Adam Amilkar Kosiński, Przewodnik heraldyczny: monografie kilkudziesięciu znakomitszych rodzin, 5 vols, Cracow and Warsaw, 1877-85, vol. 1, 1877, p. 3.

${ }^{5}$ Zielińska, Magnateria polska, p. 45.

${ }^{6}$ Ibid., pp. 136-37.

${ }^{7}$ Ibid., pp. 42-45; see also Frost, 'The Nobility of Poland-Lithuania', pp. 289-90.

8 Jerzy Michalski, 'Sejmiki poselskie 1788 roku', in idem, Studia historyczne z XVIII i XIX wieku, 2 vols, Warsaw, 2007, vol. 1, pp. 217-84 (p. 226).

${ }^{9}$ For more on this, see Witold Kula, 'Udział we władzy', in Przemiany społeczne w Królestwie Polskim, pp. 405-19; Mikołaj Getka-Kenig, 'The Genesis of the Aristocracy in Congress Poland', APH, 100, 2009, pp. 79-112. 
untouched. Neither the king nor the middle nobility had any interest in strengthening the position of the magnates, and the exclusion of the landless nobility from political life undermined the magnates' position inasmuch as the wealthiest noblemen had a long tradition of making the landless nobility dependent on them and using them in political conflicts. ${ }^{10}$ It was thanks to the efforts of the royal court that the magnates became the arch-villains in political discourse in the years immediately preceding the collapse of the Polish-Lithuanian Commonwealth. They became the main enemies of the increasingly powerful middle nobility, without which no reform of the state would have been possible. ${ }^{11}$

In such a situation the division - characteristic of Prussia, Austria and Russia - into untitled nobility and nobility with hereditary titles of baron (baron) or count (hrabia) was not only a novelty in Poland but also something that was apparently incompatible with the mood of the country towards the end of the century. The title of kniaź was traditionally recognized, but it was not associated automatically with any special social prestige. It was a mark of distant (and from the genealogical point of view sometimes imagined rather than real) kinship with sovereign rulers of Lithuania and Ruthenia, and not a factor of actual elitism within the nobility. ${ }^{12}$ An exception to this rule was the hereditary title of prince granted in the second half of the eighteenth century to the Poniatowski (after Stanisław August's ascension to the throne) and Poniński families, as well as several instances of the confirmation of aristocratic titles already possessed by other families. ${ }^{13}$ The fact is that few agnatic descendants (through the male line) of Rurik or Gediminas had the secure position of true magnates when the Polish-Lithuanian Commonwealth fell, and they owed this status only partially to their material inheritance from their monarchical ancestors. Yet at the same time there were also those who did not even come close to this status and remained on the level of the middle nobility at best, or those who had only recently

${ }^{10}$ Jerzy Jedlicki, Klejnot i bariery społeczne: Przeobrażenia szlachectwa polskiego w schytkowym okresie feudalizmu, Warsaw, 1968, pp. 146-49; see also Richard Butterwick, Poland's Last King and English Culture: Stanisław August Poniatowski 1732-1798, Oxford, 1998, pp. 295, 305; Frost, 'The Nobility of Poland-Lithuania', pp. 300-03.

${ }^{11}$ Anna Grześkowiak-Krwawicz, Regina libertas: Wolność w polskiej myśli politycznej XVIII wieku, Gdańsk, 2006, p. 179.

${ }^{12}$ Julian Bartoszewicz, 'Kniaź i książę', in idem, Studja historyczne i literackie, 3 vols, Cracow, 1880-81, vol. 3, 1881, pp.368-400 (pp. 383-84); Józef Wolff, Kniaziowie litewsko-ruscy od końca czternastego wieku, Warsaw, 1895, pp. XX-XXI.

${ }_{13}$ Tomasz Lenczewski, Genealogie rodów utytułowanych $w$ Polsce, vol. 1, Warsaw, 1996, p. XI; Tadeusz Bernatowicz, Mitra i buława: Królewskie ambicje ksiażąt w sztuce Rzeczypospolitej szlacheckiej (1697-1763), Warsaw, 2011, p. 32. 
achieved some real influence, connections and wealth (like the families of Massalski, Drucki-Lubecki, Giedroyć or Czetwertyński). ${ }^{14}$ Nor was any great social significance attached to the foreign titles of duke, margrave or count; titles which foreign rulers (primarily German emperors and popes) had granted to powerful Polish 'lords'. ${ }^{15}$ On the other hand there was a characteristic practice in the Polish-Lithuanian Commonwealth of using the term 'county' (hrabstwo) to refer to some large groups of landed estates and on this basis address their owners as counts (to some extent these symbolic territorial titles were correlated with the granting of titles by foreign rulers to the owners of such estates). ${ }^{16}$

The fact that the aristocratic titles typical of the partitioning superpowers were something new from a legal point of view did not prevent these titles from quickly spreading among the Polish nobility on an unprecedented scale, and becoming a real mark of elitism. This concerned both scions of genuinely magnate families and representatives of the better-off middle nobility who, despite the equality-promoting slogans dominating public discourse in the late eighteenth century, aspired to be symbolically elevated above the noble-born masses. The emancipation of the middle nobility - a process facilitated by, among others, senatorial promotions pushed through by Stanisław August was conducive to a rise in the individual ambitions of noble-born arrivistes, ambitions manifested in forms offered at the time by the existing socio-cultural determinants, that is the customs prevailing in the partitioning states (their new homelands) ${ }^{17}$ It should also be noted that hereditary titles offered the Polish noble elite something they had not had before - a symbolic stabilization of their family status. ${ }^{18}$

Yet the spread of aristocratic titles among the Polish nobility was not limited in the post-partition period to legally-sanctioned awards (in the form of written privileges for specific individuals and usually also their legitimate male-line descendants). The history of the post-partition process of the aristocratization of the Polish noble elite, manifested in a desire to

${ }^{14}$ See Mariusz Kowalski, Księstwa Rzeczpospolitej: Państwo magnackie jako region polityczny, Warsaw, 2013, pp. 141-42.

${ }^{15}$ Teresa Zielińska, Poczet polskich rodów arystokratycznych, Warsaw, 1997, p. 10.

${ }^{16}$ Zielińska, Magnateria polska, p. 10. Kowalski, Księstwa Rzeczpospolitej, pp. 183-88; Sławomir Górzyński, 'Tytuły w dawnej Rzeczypospolitej i obecnie - praktyka i prawo', Rocznik Polskiego Towarzystwa Heraldycznego, 8 (19), 2008, pp. 115-32 (pp. 116-19).

${ }^{17}$ For more on this topic (the example of countryside residences of new provincial leaders of the nobility), see: Mikołaj Getka-Kenig, 'Trzy pałace Hilarego Szpilowskiego: Klasycyzm a problem elitarności wśród szlachty na Mazowszu końca XVIII w.', Biuletyn Historii Sztuki, 77, 2015, 2, pp. 275-302.

${ }^{18}$ See Frost, 'The Nobility of Poland-Lithuania', pp. 288, 290. 
stress its hierarchical superiority by means of hereditary titles, also encompasses cases of widely-accepted usurpation of such titles. Scholars studying the socio-cultural history of the Polish nobility have so far paid little attention to these cases, although this neglect is unjustified. ${ }^{19}$ By limiting the phenomenon of aristocracy only to individuals privileged by law, we ignore the fact that the social ideas of the noble elite were not simply reflected in the relevant legal solutions. An analysis of the phenomenon of usurpation - that is the existence of de facto counts or barons alongside their de jure equivalents - can thus be treated as a starting point for broader research into the adaptation and resistance of the Polish nobility to the rules of social life imposed by the partitioning monarchies in such a fundamental aspect as the traditional principle of equality of noble birth.

The post-partition phenomenon of usurpation has its direct roots already in the second half of the eighteenth century, and more specifically in the reign of Stanisław August. It was then that as a result of the first partition of Poland (1772) a large number of Polish nobles were con-

${ }^{19}$ The most extensive analysis of the phenomenon of usurpation so far has been carried out by Szymon Konarski, both in Armorial de la noblesse polonaise titrée, and in the brochure 0 heraldyce i 'heraldycznym' snobizmie, which features a list of 212 such cases. In these publications Konarski appears as a legalist (he was educated as a lawyer) fighting against 'snobbery' in the name of truth and fairness with regard to families with a well-documented right to use specific titles. His opinion about any manifestations of usurpation was negative, which is why he was unable to approach the matter as a stand-alone historical problem. Tomasz Lenczewski (appearing under the pseudonym Dominik Zaroszyc) speaks in a similar spirit in the afterword to the new edition of $O$ heraldyce $i$ 'heraldycznym' snobizmie. From the socio-cultural point of view the most doubtful element in their approach (although justified from a doctrinal legal perspective) is the lumping together of all cases of usurpation, without distinguishing between those whose claims to a title met with no significant response from society and those who were able to win universal approval of their ambitions. Without a doubt more understanding of the problem of 'usurpation' as a social phenomenon from the partition era is displayed by Emanuel Rostworowski, who in his essayistic study of the history of his own family in the nineteenth century tackles the question of the 'aristocratization' of the Polish landed gentry. He understands it as both efforts to obtain a title (and the use of that title by those who obtained it) and usurpations. In his view the Rostworowskis, as counts recognized by society, were members of the same group as the Dunin-Borkowskis, counts with a title granted by the partitioner. The only difference was the legal status of their aristocratic claims, but the effect was the same, for all these families used their titles and were commonly regarded as titled - all of them were players on the same 'market of snobbery'. Szymon Konarski, Armorial de la noblesse polonaise titrée, Paris, 1958, pp. 63-75; idem, O heraldyce i 'heraldycznym' snobizmie, 2nd eds, Warsaw, 1992, pp. 27-34; Dominik Zaroszyc, 'Posłowie' in ibid., pp. 54-77 (pp. 63-68); Emanuel Rostworowski, Popioły i korzenie: szkice historyczne i rodzinne, Cracow, 1985, pp. 334-36. See also Górzyński, ‘Tytuły w dawnej Rzeczypospolitej', pp. 115-32. 
fronted directly with a legally-sanctioned gradation of their noble status. However, the broad acceptance of the use of titles in the partitioned Polish-Lithuanian Commonwealth (meaning titles in general, that is both those with a legal basis and those without it) also owed a lot to the influence of French aristocratic culture, which was strong in Poland at the time. ${ }^{20}$ Suffice it to say that the French equivalent of the count, le comte (female form: la comtesse) became, during Stanisław August's reign, a virtually ever-present element of the correspondence (often conducted in French) of representatives of families with a high position in the traditional hierarchy of prestige among the nobility. Le comte began to precede on envelopes the names of senators and their relatives, as well as other high officials. We can read a somewhat exaggerated account of a memoir from the early nineteenth century, stating that 'every female citizen of Poland, if she had several villages and a fairly well-known name, received letters addressed to madame la comtesse, and used the same title when writing herself. ${ }^{21}$ This was the source of the later popular term 'envelope count', used as a synonym of an aristocratic usurper (the title of count was in fact the main object of usurpation in Poland). ${ }^{22}$ Such an informal title testified to the relatively high position of the addressee (provided of course that the addressee actually enjoyed a high status when it came to wealth, family, or politics), and this form of address was not just an isolated instance but the norm.

The turn of the nineteenth century was marked by the spread of yet another form of aristocratization of the nobility in the Polish-Lithuanian Commonwealth, namely the addition of nine-tine and seven-tine coronets $^{23}$ to the coats of arms on signet rings, tombstones, functional objects,

20 See Joachim Lelewel, Trzy konstitucje polskie 1791, 1807, 1815, Poznań, 1861, pp. 9-10; idem, Panowanie króla polskiego Stanisława Augusta, Brussels, 1847, p. 17; Julian Błeszczyński, 'Hrabia', in Encyklopedyja powszechna, 28 vols, Warsaw, 1859-69, vol. 12, 1863, pp. 196-200 (p. 199). See also Stefan Witwicki, 'O hrabiach u nas', in Wieczory pielgrzyma: rozmaitości moralne, literackie i polityczne, 2 vols, Leipzig, 1866, vol. 2, pp. 139-56 (pp. 147, 155).

${ }^{21}$ Sabina z Gostkowskich Grzegorzewska, Pamiętniki, Warsaw, 1889, p. 165; see also Gazeta Warszawska, 25 January 1817, no. 7, supplement, p. 152.

${ }^{22}$ See for example Michał Budzyński, Wacław Rzewuski: fantazja z czasów powstania podolsko-ukraińskiego w 1831 r., Brussels, 1841, pp. 60-61.

${ }^{23}$ According to the rules of heraldry in all three partitioning monarchies, the rank of count was symbolized by a nine-tine coronet; and that of baron by a seven-tine coronet; yet in Poland (especially in the first half of the nineteenth century) sometimes no distinction between the two was made and the title of count could be symbolized by either nine or seven tines. This may have stemmed from the fact that the tines, alien to the Polish heraldic tradition as they were, were generally associated with the aristocracy. As Bishop Ludwik Łętowski (1786-1868) wrote about the situation in Galicia: 'there are names which after the fall of the country came into 
facades of residences, or decorations of their interiors. The inspiration came from the top, as Stanisław August himself, although legally not a count, used to add a count's tines to his family's coat of arms, from coins and etched portraits to clocks in the Royal Castle in Warsaw. ${ }^{24}$ In the case of tombstones, both in that period and later a count's coronet was not necessarily associated with the title, being included in the inscription. It was a means to subtly indicate the superiority of the individual in question compared to ordinary members of the nobility. In such cases a coronet may have been a compromise solution between the democratic tradition and new aristocratic aspirations among the Polish nobility. A fairly characteristic case in this context was that of the monumental tombstone of Michał Bogoria Skotnicki, made in the 1800s. Although Skotnicki did not come from a rich family, he did bear a historic name (the famous fourteenth-century Archbishop of Gniezno, Jarosław, came from his family) and married an ambitious heiress to a considerable (though only bourgeois) fortune, who funded the monument. ${ }^{25}$ While the version of it intended for a church in Florence (Skotnicki died in Italy) did not contain any aristocratic heraldic elements, such elements did appear in the version of the tombstone placed in Cracow cathedral, where the deceased established a symbolic relationship with the kings and great dignitaries of the now fallen Polish-Lithuanian Commonwealth.

Envelope countships and wilful meddling with heraldry were popular substitutes for formal awards which were unknown in the Polish-

fortunes and beautiful unions and walk around today with seven tines in a coronet they have bought for themselves.' Ludwik Łętowski, Wspomnienia pamiętnikarskie, Wrocław, 1956, pp. 101-02.

${ }^{24}$ Kazimierz Władysław Stężyński Bandtkie, Numismatyka krajowa, 2 vols, Warsaw, 1839-40, vol. 1, 1839, p. 60; Hanna Widacka, 'Ikonografia króla Stanisława Augusta w grafice XVIII wieku', Rocznik Historii Sztuki, 15, 1985, pp. 163-220 (pp. 167, 171, 174); Zuzanna Prószyńska, Zegary Stanisława Augusta, Warsaw, 1994, fig. 10, IX. In the case of the Poniatowskis, their claims to the title of count were based primarily on their alleged descent from the Italian family of Torelli. On this basis (never formally confirmed), the tile of count was used in the nineteenth century also by distant (and, according to some genealogists, doubtful) relatives of Stanisław August, who lived in the region of Kiev and accumulated considerable wealth after the partitions. See Kurier Warszawski, 3 November 1850, no. 290, p. 1548 (obituary of Olga Poniatowska née Świeykowska); Elżbieta Orman, Tahańcza Poniatowskich: Z dziejów szlachty na Ukrainie w XIX wieku, Cracow, 2009, pp. 29-34; tombstone of Maurycy Poniatowski in the Church of SS Peter and Paul in Cracow (from 1881).

${ }^{25}$ Weronika Rostworowska, 'Pomnik Michała Bogorii Skotnickiego a nekropolia wawelska na przełomie XVIII i XIX wieku', in Wzgórze wawelskie w słowie i w obrazie: $z$ badań nad kultura wieku XIX, ed. Joanna Winiewicz-Wolska and Joanna Ziętkiewicz-Kotz, Cracow, 2014, pp. 117-30 (pp. 121-23); Katarzyna Mikocka-Rachubowa, Rzeźba włoska w Polsce około 1770-1830: Katalog, Warsaw, 2016, p. 473. 
-Lithuanian Commonwealth. Significantly however, such practices were by no means discontinued after the introduction of a new legal order following the partitions, as in the case of the Habsburg subjects who were able to formally apply for a title; those with a right to do so were all agnatic descendants of senators (in the case of the comital title) and even local officials (in the case of the baronial title) ${ }^{26}$ Thus claims to aristocratic titles found support in the legislation of one of the partitioning powers, but those who actually used the titles did not always seek to have them formally recognized, even if they indeed had grounds to do so. This situation was tacitly accepted by the authorities. ${ }^{27}$ On the other hand, in the part of Poland annexed by Russia, usurpations remained the only possible solution in a situation in which throughout the nineteenth century the tsars would only sporadically grant their subjects hereditary titles..$^{28}$ In Prussia titles were not given out liberally either, although they were granted more frequently than in Russia. ${ }^{29}$

The growing popularity of titles among the nobility was a particular challenge to the government of the Kingdom of Poland (Congress Poland), established in 1815 and considered by the official propaganda to be a 'resurrected' Polish state, though in eternal union with Russia (which meant in fact that it was strongly politically dependent on Russia) and encompassing only a part of the former territories of Poland originally annexed by Prussia and Austria. In addition, the Kingdom was in many respects (also territorial, albeit to a limited extent) a successor to the Napoleonic Duchy of Warsaw, where the royal chancellery would sometimes use the title of count with reference to people who had no right to it. However the nineteenth-century historian Julian Bartoszewicz was definitely exaggerating when he wrote that 'in his official letters the king [that is the king of Saxony who was simultaneously duke of Warsaw] would refer to everyone as counts', for at that time the title of count was used courteously above all with reference to ministers and other high dignitaries. ${ }^{30}$

${ }^{26}$ Vushko, The Politics of Cultural Retreat, pp. 130-31 (erroneous information that descendants of senators could use the title of duke).

${ }^{27}$ The Austrian authorities apparently turned a blind eye to unlawful use of the title of count by Poles in Vienna no less. Tadeusz Mencel, 'Magnateria polska w Galicji w polityce władz austriackich w latach 1795-1809', in Ziemiaństwo polskie 1795-1945, ed. Janina Leskiewiczowa, Warsaw, 1985, p. 45.

${ }^{28}$ Konarski, Armorial de la noblesse, p. 56.

29 Ibid., p. 52.

${ }^{30}$ Julian Bartoszewicz, 'Tytuły honorowe rodzinne w Polsce', in Encyklopedyja powszechna, vol. 25, 1867, pp. 880-92 (p. 891). On this basis (as was in any case explicitly stated) the Duchy's minister of internal affairs, Jan Paweł Łuszczewski, was listed as count in the genealogy of the Łuszczewski family ('from documents sent to the 
The government of the Kingdom of Poland not only introduced 'honorary' Polish titles of prince, count and baron, but also carried out a verification of the titles used earlier by the new subjects of the Romanovs. Those who were unable to confirm their rights and pass an inspection by a special deputation of the Kingdom's senators had to be aware of possible financial penalties that could be imposed on them in case of insubordination. ${ }^{31}$ Such a strict approach to the matter must have been motivated by a desire to use new titles - to be granted in the future as political rewards. In the longer term (had the relative independence of the Kingdom not been interrupted by the November Uprising of 1830) they might have become an important factor in the emergence of a new elite of the 'resurrected' state, as was the case of the first governor of the Kingdom, Józef Zajączek, a scion of the middle nobility who in 1818 was made a prince (although he was childless); or Maurycy Hauke, the minister of war, who in 1829 was made a count even though he did not even come from a noble family. ${ }^{32}$

The practice of confirmations in the Kingdom of Poland proved to be quite liberal, especially when it came to people with links to the government or the royal court. For example, there were several instances of acceptance of royal diplomas from the period of the Duchy of Warsaw and the Kingdom of Poland in which the name of the person granted the rank of marshal, chamberlain or Kammerjunker was accompanied by the title of count, and the same was true also of some ministerial nominations. ${ }^{33}$ Some, like Stanisław Kostka Potocki, argued that 'the whole family undeniably used the title of count in Poland and overseas and had it commonly granted'. Moreover, Potocki pointed to the Austrian comital diploma given to his aunt, which at that time was the only document of this kind directly concerning a member of his family and referring to

publisher') included in the new edition of Kasper Niesiecki's armorial edited by Jan Nepomucen Bobrowicz: Kacper Niesiecki, Herbarz polski, 10 vols, Leipzig, 1839-46, vol. 6, 1841, pp. 293-94. See also Stanisław Dołęga Cieszkowski, Senatorowie Księstwa Warszawskiego i Królestwa Kongressowego 1807-1815-1831, Warsaw, 1891, p. 49.

${ }^{31}$ Royal decision raising individuals to the nobility and granting honorary titles of 5/17 June 1817, Article 14: 'No one would be allowed to use honorary Polish titles, if they had not been granted the right to do so before the proclamation of the Kingdom of Poland either by old national laws or by Polish kings or by the rulers of the country. Those who unlawfully use any title in their private or public endeavours will be, every time they are reported to the police, punished by having to pay a fine equal in its amount to the levy paid, under Article 12 hereof, for receiving the title that has been appropriated.' Dziennik Praw Królestwa Polskiego, [1817], 3, no. 12, pp. 277-78.

32 Getka-Kenig, 'The Genesis of the Aristocracy', pp. 104-05, 110.

${ }^{33}$ Records concerning the legitimization of honorary titles from the former Senate of the Kingdom of Poland, AGAD, Heroldia Królestwa Polskiego, no. 1, 2, 3, 4, 5. 
the Potockis as 'counts'. The problem is that it did not grant that rank to them explicitly. Thus Potocki tried to convince the senatorial deputation that his family had not been granted the title of count in Galicia precisely because the Potockis had been regarded as counts already and there was no need for issuing a diploma to them. ${ }^{34}$ As the matter concerned one of the wealthiest landowners in the Kingdom of Poland and one of the state's highest dignitaries (not only a minister, but also senator and even president of the Senate), this explanation was sufficient for him to obtain the necessary confirmation. ${ }^{35}$

In any case, no one at that time questioned Potocki's aristocratic status, with or without a lawful title. Significantly, already in the early 1780 s Stanisław August referred to him as count in private correspondence with third parties. ${ }^{36}$ Yet the situation was different in the case of many other counts whose titles, legalized in the Kingdom, could be seen as a dissonance when compared with the short history of the fame, merits, or wealth of their families. In this respect we have a characteristic letter received by Potocki from Antoni Rudziński (whose mother came from the Potocki family) in connection with the legitimization campaign. Childless and with one foot in the grave Rudziński, the son and grandson of voivodes and great-grandson of a major castellan in the male line, asked his well-connected cousin to support him not so much in his legitimization efforts, but in efforts to obtain the comital title, because 'in my old age I have this desire and ambition to be able to boast of a title'. Yet as we read the letter we learn that he was motivated more by envy caused by the aristocratic elevation of 'the Kicińskis, Ostrowskis, Poletyłs, Męcińskis, Aleksandrowiczs, Jezierskis etc.', whose lineage was no better than his and who, in his opinion, "had no other right to it than the fact that their fathers were senators' and he could 'pride [himself] on it as well.${ }^{37}$ It does not matter in this case that all the families mentioned by him (promoted largely by Stanisław August and being of no special rank previously) simply received a confirmation of their Prussian and Austrian titles granted to them around 1800, of which Rudziński may have been unaware. Above

${ }^{34}$ S.K. Potocki to the Senate Deputation, 9 December 1819, AGAD, Archiwum Gospodarcze Wilanowskie, Archiwum Główne Potockich, no. 121, pp. 8-9.

${ }^{35}$ See also S.K. Potocki's letter to the minister and secretary of state Ignacy Sobolewski of 26 December 1816, AGAD, Archiwum Publiczne Potockich (hereafter APP), no. 267, p. 20.

${ }^{36}$ Stanisław August to A. Deboli, 9 September 1782, in Korespondencja polityczna Stanisława Augusta: Augustyn Deboli 1782, ed. Ewa Zielińska and Adam Danilczyk, Warsaw, 2017, p. 218.

${ }^{37}$ A. Rudziński to S.K. Potocki, 6 February 1820, AGAD, APP, no. 265, vol. 8, pp. 112-14. 
all the letter testifies to a sense of threat on the part of the old elite (the Rudzińskis' social position, not to mention their family relations, was decidedly more remarkable than that of the counts mentioned by him) as a result of the introduction of new factors of prestige within the highest elite such as hereditary titles.

We should note, however, that many members of the Potocki family, especially those with the highest stature in terms of political influence and wealth, did not bother with trying to legitimize their commonly recognized rank of counts. This group included the owners of Krzeszowice near Cracow and their close cousins, the owners of the Łańcut entail, as well as their more distant relatives, descendants of Szczęsny Potocki from Tulczyn in Podolia, one of the richest magnates in the Polish-Lithuanian Commonwealth on the eve of the country's fall. In the case of the latter group, the comital diploma was obtained only at the beginning of the twentieth century by the sole living great-grandson in the male line of the infamous marshal of the Targowica Confederation, who himself freely used the title of count and was addressed as one. ${ }^{38}$ Moreover, it seems that the governments of the partitioning powers were aware of the lack of a legal basis for the title on the part of many Potockis, and yet they accepted this state of usurpation. Cases whereby they were ostentatiously relegated to the rank of ordinary nobility (as in the case of the Governor of Galicia, Agenor Goluchowski, who apparently forbade the use of the comital title with regard to the Potockis in official documents in response to the social ostracism he experienced as an aristocratic nouveau riche) were rare. ${ }^{39}$

The case of the Potockis, that is a family in which the number of those actually using the title was much higher than that of those who had a legal right to do so, was by no means isolated. In the nineteenth century there were plenty of examples of the title being used unlawfully by many collateral relatives of individuals who had received diplomas granting the right to use the title only to them and their descendants. Thus there were plenty of various Mycielskis, Chodkiewiczs, Mostowskis, Szembeks, Moszyńskis,

38 See Jerzy Łojek, Potomkowie Szczęsnego: Dzieje fortuny Potockich z Tulczyna 17991921, Lublin, 1981, pp. 31-32. For more on the rights of various members of the Potocki family to the comital title, see Sławomir Górzyński, Arystokracja polska w Galicji: Studium heraldyczno-genealogiczne, Warsaw, 2009, pp. 299-307.

${ }^{39}$ Kazimierz Chłędowski, Pamiętniki, 2 vols, Wrocław, 1951, vol. 1, p. 252. Sławomir Górzyński mentions an intriguing reference in Viennese documents concerning noble titles and confirming the right to use the title of count by one of the Potockis of Łańcut despite the lack of any formal basis (and thus without requiring one for them). See Górzyński, Arystokracja polska, p. 302. 
Walewskis, Romers, Załuskis, Czapskis, Sobańskis and Ledóchowskis (often wealthy and well-connected, which constituted the basis for their aristocratic claims) who used the title of count or were addressed as such by others (including government representatives) without any legal basis. In addition, there are also known cases of persons being addressed as count only because of a similarity of names, although the individual in question did not come from the same family as the man who had once received this aristocratic title from some monarch. A paradoxical example of this phenomenon was the head of the Senate's deputation for the legitimization of titles in the Kingdom of Poland, Piotr Bieliński of the Szeliga coat of arms. Long before he received the title of count in the Kingdom towards the end of his life, he had been using the title and was referred to as count in official documents in the Duchy of Warsaw. This usage was probably determined by his aristocratic surname, although in fact he had nothing in common with the 'great' Bielińskis of the Junosza coat of arms, who were part of the magnate elite in the late seventeenth and early eighteenth century. ${ }^{40}$

Returning to the results of the work of the deputation headed by Bieliński, in 1824 it published a list of people who were deemed as having a right to use hereditary titles. ${ }^{41}$ The list was to be the basis for imposing legal sanctions on those who used the titles in the Kingdom but were not included in the list. Yet even the government of the 'resurrected' Poland, including the monarch, did not observe its own regulations. There were still plenty of official documents in which various individuals were assigned aristocratic titles unlawfully. It is, therefore, hardly surprising that 'usurpations' were common, as in the case of Janusz Rostworowski, whom Tsar Nicholas I gave the honorary office of Kammerjunker of the Polish royal court in 1830, addressing him in an official document as a count. ${ }^{42}$ The case of the Rostworowskis, the protagonists of the oft-quoted twentieth-cetury anecdote about the hierarchical nature of the Polish (strictly speaking, Galician) aristocracy, ${ }^{43}$ deserves particular attention because of the spectacular success this

${ }^{40}$ Mikołaj Getka-Kenig, Ojcowie ‘wskrzeszonej’ ojczyzny: Senat w rzeczywistości społeczno-politycznej Księstwa Warszawskiego, Warsaw, 2013, p. 41.

${ }^{41}$ See Kosiński, Przewodnik heraldyczny, vol.1, pp. 210-16.

${ }^{42}$ See Kurier Warszawski, 5 July 1830, no. 177, p. 933.

43 'A Rostworowski would look down on a Baworowski, a Skarbek or a Fredro, while the Lubomirskis, the Sapiehas and the Potockis felt they had reached dizzy heights in comparison with all the rest.' Walerian Meysztowicz, To co trwałe: gawedy o czasach i ludziach, London, 1974, p. 104. According to Meysztowicz, the author of the anecdote is most likely Władysław Skrzyński (1873-1937), a diplomat from the period of the Second Polish Republic, closely related to many lawfully titled families (such as the Baworowskis or the Fredros). 
family achieved with regard to social acceptance of its comital title, despite the fact that no member of the Rostworowski family was ever granted the title formally.

The beginnings of the Rostworowskis' comital title date back to at least the end of the eighteenth century, to Galicia, where we can find Janusz's grandfather, Andrzej Rostworowski. He was a judge of Czersk, starost of Liw and deputy to the Great Diet (Sejm Wielki), married to Józefa née Komorowska, daughter of the castellan of Santok (Rostworowski's father was the castellan of Zakroczym, who, like the castellan of Santok, was a minor senator). In 1793 Andrzej's mother-in-law, Antonina Szeptycka née Pawłowska (Komorowska by her first marriage) managed to obtain an Austrian title of count for her children from her first marriage, including three daughters, who were included in the imperial diploma with their husbands' titles: Józefa Countess Rostworowska, Kordula Countess Potocka and Antonina Countess Ilińska. ${ }^{44}$ Notably, none of these three titles - of the Rostworowskis, the Potockis and the Ilińskis - had any basis in law at that time. ${ }^{45}$ The Viennese officials did not check Szeptycka's request with regard to the aristocratic titles of her sons-in-law, especially given the fact that they had earlier been confirmed by the local Galician authorities. This was the first known case of the Rostworowskis' comital title being accepted in official documents as obvious and requiring no proof. Andrzej Rostworowski did not care about proof in any case, using the title of count and thus being regarded as titled. ${ }^{46}$ Various genealogical studies inform us that in 1801 he and his brother Franciszek Ksawery apparently succeeded in obtaining an Austrian comital title. ${ }^{47}$ According to Adam Amilkar Kosiński, 'as subjects of a foreign state (Prussia) they could not accept [it] and then, as the political situation in the country changed, neglected to have it legalized. ${ }^{48}$ Another genealogist, Aleksander Włodarski, who drew on Seweryn Uruski's notes, presented the situation in the following man-

${ }^{44}$ Górzyński, Arystokracja polska, p. 191; Poczet szlachty galicyjskiej i bukowińskiej, Lviv, 1857, p. 115.

${ }^{45}$ In the case of the latter family, the right to use the title of count in Russia was granted only to Henryk and Jan August Stanisław (Janusz) Iliński, sons of Antonina née Komorowska. Konarski, Armorial de la noblesse, p. 199.

${ }^{46}$ Stanisław Jan Rostworowski, Monografia rodziny Rostworowskich. Lata 1386-2012, 2 vols, Warsaw, 2013, vol. 1, p. 220.

${ }^{47}$ Twentieth-century genealogical literature contains references to the granting of the title in Austria to Andrzej Rostworowski in 1793 (this probably concerns the diploma issued to the Komorowskis, which mentions Countess Rostworowska, that is Andrzej's wife), alongside the 1801 grant. See Polska encyklopedia szlachecka, ed. S.J. Starykoń-Kasprzycki, Warsaw, 1935-38, vol. 10, 1938, p. 277.

${ }^{48}$ Kosiński, Przewodnik heraldyczny, p. 555. 
ner: 'they apparently [...] received the Austrian comital title, which, however, was not granted to them in the Kingdom of Poland. ${ }^{49}$ It should be noted that Uruski (who himself was a lawful Austrian count ${ }^{50}$ ) included the Rostworowskis in the list of Polish titled families published in the mid-nineteenth century, but said nothing about the circumstances in which they had obtained their comital title. ${ }^{51}$ The Viennese archives lack not only such a diploma, but also any traces of an application submitted in the matter around $1801 .^{52}$

What has survived is a letter of application from 1828. It was submitted not by one of the Rostworowskis, but by Andrzej's sister-in-law, Kordula Potocka née Komorowska, who personally gave the emperor the letter, asking for the title not to be granted to the Rostworowskis but for it to by 'confirmed' in Austria. ${ }^{53}$ The application received an unequivocally positive opinion from the Regional Commission of the Estates of the Kingdom of Galicia (Krajowa Komisja Stanów Królestwa Galicji), made up solely of Poles, but was rejected in Vienna because of a negative reponse from Austrian officials, who found a number of procedural errors making it impossible for Rostworowski to be recognized as a Galician count. Leaving aside the question of his failing to pay sufficient taxes, the officials stressed the expiry of the original regulation concerning the granting of titles to the descendants of former Polish officials. It was no longer possible to grant them on the basis of lineage, but only on the basis of personal service rendered to the imperial house. Andrzej had not rendered any; moreover, during the Polish-Austrian war of 1809 he was a member of the regional government of Eastern Galicia, which had rebelled against the Habsburgs. ${ }^{54}$

We may wonder about the motivation behind Kordula Potocka's application in a situation in which Rostworowski had had no previous problems with using the title of count and needed no diplomas. The answer lies in a letter of the Galician Commission of the Estates, in which we read that after obtaining a confirmation in Galicia, Rostworowski would seek to have his title confirmed in the Kingdom, where his two sons lived. Given the chronology - the application was submitted a few days before the end

${ }^{49}$ Seweryn Uruski, Rodzina: herbarz szlachty polskiej, ed. Aleksander Włodarski, 15 vols, Warsaw, 1904-31, vol. 15, 1931, p. 264.

${ }^{50}$ Górzyński, Arystokracja polska, p. 375.

51 [Seweryn Uruski], Notices sur les familles illustres et titrées de la Pologne, Paris, 1862, p. 167.

${ }^{52}$ Rostworowski, Monografia rodziny, vol. 1, p. 215.

${ }^{53}$ Ibid., vol. 1, pp. 221-24.

${ }^{54}$ See Jerzy Kowecki, 'Rostworowski Andrzej h. Nałęcz (1745-1831)', in PSB, vol. 32, Wrocław, 1989, p. 176. 
of 1828 - we can guess that the imperial diploma was to support the efforts of his sons, officers of the Kingdom of Poland's army, to have their nobility formally legitimized, a requirement introduced in 1828 by the Kingdom's government for all ranks starting with second lieutenant..$^{55}$ Presumably they wanted to have an officially recognized title and not present themselves as ordinary noblemen, and an Austrian diploma would be useful in such a case.

The matter of formal recognition of the Rostworowskis' title appeared also after the November Uprising (1830-31) in the Kingdom of Poland, in connection with yet another legitimization campaign, this time encompassing all noblemen living within the Kingdom's borders (in accordance with the law of the Russian Empire, of which the Kingdom was then an autonomous part). In their application of 1836 Andrzej's four nephews did not fail to mention their traditional right to the title, noting that they deserved it because they descended from the family of Nałęcz, the oldest Polish counts (as the non-hereditary medieval office of comes was translated), alongside the families of Górka and Tęczyński. They wrote explicitly that: 'We submit it to the Heraldic Authority for wise consideration whether those descended directly from the ancient family of Nałęcz have the right to use the title of count, for which we do not have an original diploma, though very few of the counts recognized by the Senate of the Kingdom can boast one for reason of too great a distance in time.' One version of the application ended with the following sentence: 'We hope that the title of count will be granted to us', while another version put it more boldly: 'We hope that our comital title will be confirmed'. ${ }^{56}$ Their noble status was eventually confirmed, but without the title of count. Yet this was no obstacle for the title still being used by members of the family and by others who addressed them on various occasions. As I have already stated, with the development of genealogical literature in the nineteenth century references to the Rostworowskis' comital title began to appear in such publications, both Polish and foreign, including the Almanach de Gotha, which in 1862 featured a genealogy of the Rostworowskis in the 35th volume of the Genealogisches Taschenbuch der gräflichen Häuser. ${ }^{57}$

${ }^{55}$ Marek Tarczyński, Generalicja powstania listopadowego, Warsaw, 1988, p. 175.

${ }^{56}$ Rostworowski, Monografia rodziny, vol. 2, pp. 1666-67.

${ }^{57}$ Gothaisches genealogisches Taschenbuch der gräflichen Häuser, 35, 1862, pp. 725-28. It also included a reference to an Austrian imperial diploma (dated 30 July 1801) for Andrzej and his brother Franciszek Ksawery Rostworowski as the basis of their title. This entry from the Almanach de Gotha may have been the basis of Kosiński's and Włodarski's (Uruski's?) opinions concerning the grant of 1801. The arrangement of 
The Rostworowskis' aristocratic success (concerning not only the descendants of Andrzej and his brother, but also their more distant relatives, who were addressed as counts as well ${ }^{58}$ ) is all the more spectacular given the fact that they were never particularly wealthy nor politically influential in comparison with, for example, the Potocki family. Throughout their pre-partition history the Rostworowskis had only three minor castellans in their ranks, while the Potockis had no fewer than two hetmans, one primate, ten voivodes, four major and two minor castellans in the first half of the eighteenth century alone. ${ }^{59}$ Still, the Rostworowskis were regarded as authentic counts, a state of affairs undoubtedly influenced, in addition to their family connections (incluging with the Potockis ${ }^{60}$ ), by their unquestionably ancient lineage ${ }^{61}$ It is true that there were still quite a lot of representatives of very old Polish noble families in the nineteenth century. However, there was a more modest representation of descendants of famous medieval clans (like the Nałęczs) among the aristocracy, dominated by members of families with a shorter lineage and families which had been of no particular significance in the first centuries of Polish statehood (this applied also to the Potockis who had no outstanding ancestors before the seventeenth century ${ }^{62}$ ).

The need for a connection to the oldest period in the nation's history may have been the reason behind this characteristic tolerance for the comital status of the Rostworowskis, who having achieved the minimum level of wealth and family connections necessary in the nineteenth

the genealogy presented there (largely incorrect in the case of biographical information about the various members of the family) suggests that its author was Juliusz Rostworowski (1814-74), a grandson of Andrzej and brother of Janusz.

${ }^{58}$ Rostworowski, Monografia rodziny, vol. 2, pp. 2161-62. See also Stanisław Aleksander Boleścic-Kozłowski, Henryk Sienkiewicz i ród jego, Warsaw, 1917, p. 30.

${ }^{59}$ Uruski, Rodzina, vol. 15, p. 264; Zielińska, Magnateria polska, p. 169.

${ }^{60}$ In addition to the relation through the Komorowskis (it was, in fact, a double connection, for Kordula Potocka and Józefa Rostworowska's sister was Gertruda, Szczęsny Potocki's unhappy first wife), the Rostworowskis from Andrzej's line were related to the Potockis also in the paternal line - Andrzej's daughter Marianna married the son of the voivode of Bełz, Adam Potocki (incidentally, Kordula née Komorowska's stepson), while his grandson Adam Rostworowski married Leonia Potocka, great-granddaughter of the castellan of Lviv, heiress to the Tykocin estates. In addition Janusz, Andrzej's grandson, married the widow of Franciszek Potocki, a close relative of the Potockis from Krzeszowice and Łańcut.

${ }^{61}$ See Ludwik Hieronim Morstin, Spotkania z ludźmi, Cracow, 1957, p. 88 ('very old nobility and very young aristocracy' - an opinion from the perspective of the early twentieth century).

${ }^{62}$ See Marian Wolski, The Potocki Family of the Pilawa Coat of Arms: A Study of Family History and Estates until the Early $17^{\text {th }}$ Century, Cracow, 2018. 
century in any aristocratic claims, were able to consolidate their comital identity without any controversy. ${ }^{63}$ It should be added that after the First World War and the ban on public use of all aristocratic titles in reborn Poland (under the March Constitution of 1921), members of the 'Family association of the Counts Rostworowski' raised, during one of their meetings, the question of the appropriateness of using the title, the legal basis of which was doubtful even to themselves. The response was that it was not a matter of law but of tradition. ${ }^{64}$ After all, for generations the Rostworowskis had been regarded as counts and the ancient nature of the claim legitimized it.

In ending the discussion of this one family, it is worth noting that already in the nineteenth century some of the Rostworowskis apparently had a problem with the fact that their comital title had no legal basis. Not all used the title in every situation, as is evidenced by the tombstone erected for himself and family by Janusz Rostworowski the afore-mentioned Kammerjunker (later chamberlain and equerry of the court, secretary of the chancellery of the Heraldic Authority of the Kingdom as well as special affairs officer of the Russian governor, Ivan Paskevich ${ }^{65}$ ) at the Powązki Cemetery in Warsaw. ${ }^{66}$ Not all the Rostworowskis buried there have inscriptions with the title; moreover Janusz himself, even though he used the title of count on various occasions throughout his life, omitted it from the inscription of his wife, who predeceased him (although he did include the title in the case of her first husband, who had an official confirmation of it: 'by her first marriage Countess Franciszek Potocka, by her second marriage Nałęcz Rostworowska'). However, his heirs commemorated him as 'Janusz Count Rostworowski' on the tombstone placed below (it should be noted that those of the Rostworowskis who are listed on the tombstone without a title died before Janusz and their inscriptions must have been made under his control -

${ }^{63}$ Similar conclusions can be drawn in the case of the Ciechanowieckis, who in the nineteenth century owned a large estate, Boczejków, in Lithuania (then part of Russia). According to the authors of a monograph of the family, the fact that they used the title of count without a formal grant may have been linked to their evident desire to stress their ancient lineage from the historic magnate family of Kiszka. Henryk Lulewicz, Andrzej Rachuba and Jolanta Sikorska-Kulesza, 'Wstęp', in Dzieje rodziny Ciechanowieckich herbu Dąbrowa (XIV-XXI wiek), ed. Andrzej Rachuba, Warsaw, 2013, pp. 16-17.

${ }^{64}$ Rostworowski, Monografia rodziny, vol. 2, p. 1472.

${ }^{65}$ Stanisław Konarski, 'Rostworowski Janusz (1811-1891)', in PSB, vol. 32, Wrocław, 1989 , p. 211.

${ }^{66}$ Cmentarz powazkowski w Warszawie: Materiały inwentaryzacyjne, ed. Andrzej Biernat and Barbara Biernat, 3 vols, Warsaw: 1980-94, vol.1, 1980, p. 54. 
in addition, they, too, have the coat of arms mentioned before their family name) ${ }^{67}$

What is significant in this case is the reference to the Nałęcz coat of arms as a kind of alternative to an aristocratic title. If we were dealing with an ordinary member of the bourgeoisie of noble descent, without any connection to the aristocracy, we would most likely be treating the coat of arms standing before the family name (and functioning as a family sobriquet) as a desire to stress one's noble status. This was a common practice in the nineteenth century. Yet in this case we are dealing with a 'lord' with an established position in Warsaw's aristocratic community, ${ }^{68}$ who did not need to prove his noble lineage to anybody. Thus it seems that such a manifestation was more of an expression of his pride in his direct (and unchallenged) lineage from the House of Nałęcz, which meant more to him than the title of count used on a daily basis. Similar impressions may emerge as we read inscriptions on another tombstone in this Warsaw cemetery erected towards the end of the nineteenth century for the son of Janusz's cousin, Stefan Rostworowski, and funded by his wife, Józefa née Lubieniecka (incidentally, her family did not have such a distinguished genealogy as the Rostworowskis, but it did have a legally recognized comital title granted to her grandfather). ${ }^{69}$ Significantly, in the surviving certificate of death the deceased is listed as 'Stefan Count Rostworowski' ${ }^{70}$ but the inscription reads 'Stefan Nałęcz Rostworowski'. His higher noble status is evidenced only by comital coronets above the low-relief coats of arms.

The case of the Rostworowskis as a family none of whose representatives had a legally recognized title, but who were commonly regarded as a family of counts, was by no means exceptional. There were analogous situations in the nineteenth century, especially in the part of Poland annexed by Russia, to mention only the Worcels (Worcells), the Steckis and the Olizars from Volhynia; the Pociejs and the Sołtans from Lithuania; or the Sołtyks from the Kingdom. All these families were wealthy and had aristocratic connections, but their status did not have long roots in the

${ }^{67}$ See also Kurier Warszawski, 3 August 1891, no. 212, p. 2; 4 August 1891, no. 213, p. 7.

${ }^{68}$ See Stanisław Jan Rostworowski, 'W kręgu arystokratów respektujących władzę cesarzy Wszech Rosji i królów Polski', Rocznik Mazowiecki, 18, 2006, pp. 182-203.

${ }^{69}$ Cmentarz powazkowski, vol. 1, pp. 346-47; on the Lubienieckis' title: Górzyński, Arystokracja polska, p. 233.

${ }^{70}$ Records of the Roman Catholic parish of St Alexander in Warsaw, 1889, certificate of death no. 452: 〈https://szukajwarchiwach.pl/72/162/0/-/113/skan/full/hr2d6yD0_ ZLPsTSudIVGAg $>$ [accessed 1 March 2021]. 
pre-partition period. In the eighteenth century their representatives were only rarely granted (rather less important) seats in the Senate or various central-level dignities.

An exception is the family of Pociej, true magnates who had maintained a high position since the seventeenth century, as well as the Soltyk family, represented in the Senate several times throughout the eighteenth century, and also among the voivodes. After the November Uprising the Soltyks invoked the granting of the title of count in 1811 to the speaker of the Sejm of the Duchy of Warsaw, Stanisław Soltyk. ${ }^{71}$ Yet the title was also used at the time by Stanisław's relatives in the collateral line who lived in Galicia. The explanation for this was most likely about the title being pro forma included in the nomination diploma or another official royal document concerning Stanisław Sołtyk's office. Significantly, the French resident in Napoleonic Warsaw Édouard Bignon mentioned 'le comte Soltyk' in his reports sent to Paris, and the Saxon minister Senfft mentioned the title next to Sołtyk's name in his memoirs. ${ }^{72}$ Soltyk was thus seen as a count in the eyes of foreigners, including the Duchy's monarch, the Saxon King Frederick Augustus. The post-partition mentality and unique approach to the issue of the legal sanctioning of aristocratic status is well evidenced by the situation in which the head of the deputation for the legitimization of titles, Piotr Bieliński (that is, a man who should have known who could be addressed as count in the light of the existing legal regulations) presided in 1827-28 over the Kingdom of Poland's parliamentary trial of 'Stanisław Count Sołtyk', accused of membership in a secret society and high treason. Sołtyk's comital title was used in almost all contexts in the trial records signed by Bieliński. ${ }^{73}$ As we can see, legal sanction did not matter much. It did support claims to aristocratic status, but it was not necessary for the latter to be recognized in society, or for people to be able to use the title of count in various situations and be addressed as such also by those who should, in theory, have been against 'usurpations' of this kind.

To sum up, this non-legal 'life' of titles was characteristic of the Polish nineteenth-century aristocratic identity, which was an amalgam

${ }^{71}$ See Roman Sołtyk, 'O związkach przedrewolucyjnych', Pamiętnik Emigracji, 3, 1833, no. 8: brochure Jan Albert Jagiellończyk (of 21 May), pp. 2-5. See also Getka-Kenig, Ojcowie 'wskrzeszonej' ojczyzny, p. 168.

${ }^{72}$ Report of 10 September 1811, in Instrukcye i depesze rezydentów francuskich $w$ Warszawie 1807-1813, ed. Marceli Handelsman, 2 vols, Cracow, 1914, vol. 1, p. 412; Friedrich Christian Ludwig Senfft von Pilsach, Mémoires, Leipzig, 1863, p. 157.

${ }^{73}$ Sąd sejmowy 1827-1829 na przestępców stanu: urzędowe akta, ed. Tadeusz Bieczyński, Poznań, 1873, passim. 
of a cult of pre-partition tradition and efforts to assimilate in the post-partition conditions. While hereditary titles as a mark of prestige were accepted by Polish nobles who were confronted with the erosion of the old system of titular offices, the strict observance of the requirement of their legal confirmation was not compatible with the traditional mentality of the nobility. This ambivalent social status of formal grants and confirmations of titles is worth comparing with a much wider phenomenon, that is the legitimization of ordinary noble status in the partition period, for example in the Kingdom of Poland after the November Uprising (and the introduction of the institution of a Russian-style heraldic authority). Research conducted so far demonstrates a link between efforts to have a claim to noble status legitimized and ambitions relating to a career in public administration. Those who did not care about such a career or did not have such close ties with the administrative apparatus did not really need a formal confirmation of their noble pedigree. ${ }^{74}$ This might explain why, for example, Janusz Rostworowski, a dignitary (and former official of the Heraldic Authority) did not commemorate his late wife as a countess, and cousins as counts.

As we can thus see, titles granted by the partitioning powers (or the pope, not to mention other European monarchs, although they rarely granted titles to Poles) in accordance with their rules did not prove to be a decisive factor determining the structure of the Polish noble elite. The 'usurpations', which lasted successfully for generations (especially 'usurpations' concerning families whose representatives never received a legal sanction for their claims to hereditary titles, although at the same time they had some specific ideas of their alleged formal basis, like the Rostworowskis, who claimed descent from medieval comites, or the Soltyks, who invoked a grant from the Duke of Warsaw) testify to the fact that it is impossible to place the unique phenomenon of the Polish aristocracy of the partition period within the narrow framework of formal privilege rooted in foreign laws. That privilege could at best sanction rather than shape Polish social reality with regard to the noble elite.

(Translated by Anna Kijak)

(Proofreading by James Hartzell)

${ }^{74}$ Jedlicki, Klejnot i bariery społeczne, p. 427. 


\section{Summary}

In the long nineteenth century hereditary titles as a mark of aristocratic prestige were generally accepted by Polish nobles who were confronted with the erosion of the pre-partition system of personal titular offices. However, the history of the post-partition process of aristocratization of the Polish noble elite, manifested in a desire to stress its hierarchical superiority by means of hereditary titles, also encompasses cases of widely-accepted usurpation of such titles, especially in the case of families with long and established traditions of high social status in the Polish-Lithuanian Commonwealth or even in the medieval Polish monarchy. The strict observance of the requirement of the legal confirmation of such titles apparently was not compatible with the traditional mentality of the Polish nobility. Titles granted by the partitioners did not prove to be a decisive factor determining the internal structure of the Polish noble elite. The 'usurpations' of aristocratic titles, which lasted successfully for generations in some families, testify to the fact that it is impossible to place the unique phenomenon of the Polish aristocracy of the partition period within the narrow framework of formal privilege rooted in foreign laws. That privilege could at best sanction rather than shape Polish social reality with regard to the noble elite.

(Translated by Anna Kijak)

(Proofreading by James Hartzell)

\section{Bibliography}

\section{Printed sources}

Chłędowski, Kazimierz, Pamiętniki, ed. Antoni Knot, 2 vols, Wrocław: Zakład Narodowy im. Ossolińskich, 1951, vol. 1.

Dziennik Praw Królestwa Polskiego, [1817], 3, no. 12.

Gothaisches genealogisches Taschenbuch der gräflichen Häuser, 35, 1862.

Grzegorzewska, Sabina z Gostkowskich, Pamiętniki, Warsaw: Redakcja 'Kroniki Rodzinnej', 1889.

Instrukcye i depesze rezydentów francuskich $w$ Warszawie 1807-1813, ed. Marceli Handelsman, 2 vols, Cracow: Akademia Umiejętności and Towarzystwo Popierania Wydawnictw Akademii Umiejętności, 1914, vol. 1.

Korespondencja polityczna Stanisława Augusta: Augustyn Deboli: 1782, ed. Ewa Zielińska and Adam Danilczyk, Warsaw: Instytut Historii im. Tadeusza Manteuffla PAN, 2017.

Łętowski, Ludwik, Wspomnienia pamiętnikarskie, Wrocław, 1956.

Meysztowicz, Walerian, To co trwałe: gawędy o czasach i ludziach, London: Polska Fundacja Kulturalna, 1974.

Morstin, Ludwik Hieronim, Spotkania z ludźmi, Cracow: Wydawnictwo Literackie, 1957. 
Poczet szlachty galicyjskiej i bukowińskiej, Lviv: Instytut Stauropigiański, 1857.

Sąd sejmowy 1827-1829 na przestępców stanu: urzędowe akta, ed. Tadeusz Bieczyński, Poznań: [n. pub.], 1873.

Senfft von Pilsach, Friedrich Christian Ludwig, Mémoires, Leipzig: Veit \& Comp., 1863.

Sołtyk, Roman, 'O związkach przedrewolucyjnych', Pamiętnik Emigracji, 3, 1833, no. 8: brochure Jan Albert Jagiellończyk, pp. 2-5.

\section{Secondary literature}

Bartoszewicz, Julian, ‘Kniaź i książę’, in idem, Studja historyczne i literackie, 3 vols, Cracow: nakładem Kazimierza Bartoszewicza, 1880-81, vol. 3, 1881, pp.368-400.

Bartoszewicz, Julian, 'Tytuły honorowe rodzinne w Polsce', in Encyklopedyja powszechna, 28 vols, Warsaw: S. Orgelbrand, 1859-69, vol. 25, 1867, pp. 880-92.

Bernatowicz, Tadeusz, Mitra i buława: Królewskie ambicje książat w sztuce Rzeczypospolitej szlacheckiej (1697-1763), Warsaw: Wydawnictwa Uniwersytetu Warszawskiego, 2011.

Błeszczyński, Julian, 'Hrabia', in Encyklopedyja powszechna, 28 vols, Warsaw: S. Orgelbrand, 1859-69, vol. 12, 1863, pp. 196-200.

Boleścic-Kozłowski, Stanisław Aleksander, Henryk Sienkiewicz i ród jego, Warsaw: Gebethner i Wolff; Cracow: Gebethner i Spółka, 1917.

Budzyński, Michał, Wacław Rzewuski: fantazja z czasów powstania podolsko-ukraińskiego w 1831 r., Brussels: [n. pub.], 1841.

Butterwick, Richard, Poland's Last King and English Culture: Stanisław August Poniatowski 1732-1798, Oxford: Clarendon, 1998.

Cieszkowski, Stanisław Dołęga, Senatorowie Księstwa Warszawskiego i Królestwa Kongressowego 1807-1815-1831, Warsaw: [n. pub.], 1891.

Cmentarz powazkowski w Warszawie: Materiaty inwentaryzacyjne, ed. Andrzej Biernat and Barbara Biernat, 3 vols, Warsaw: Wydawnictwa Uniwersytetu Warszawskiego, 1980-94, vol. 1, 1980.

Frost, Robert I., 'The Nobility of Poland-Lithuania, 1569-1795', in The European Nobilities in the Seventeenth and Eighteenth Centuries, 2nd edn, 2 vols, ed. Hamish M. Scott, Basingstoke and New York: Palgrave Macmillan, 2007, vol. 2, pp. 266-310.

Getka-Kenig, Mikołaj, 'The Genesis of the Aristocracy in Congress Poland', APH, 100, 2009, pp. 79-112.

Getka-Kenig, Mikołaj, Ojcowie ‘wskrzeszonej’ ojczyzny: Senat w rzeczywistości społeczno-politycznej Księstwa Warszawskiego, Warsaw: Neriton, 2013.

Getka-Kenig, Mikołaj, 'Trzy pałace Hilarego Szpilowskiego: Klasycyzm a problem elitarności wśród szlachty na Mazowszu końca XVIII w.', Biuletyn Historii Sztuki, 77, 2015, 2, pp. 275-302.

Górzyński, Sławomir, Arystokracja polska w Galicji: Studium heraldyczno-genealogiczne, Warsaw: DiG, 2009.

Górzyński, Sławomir, ‘Tytuły w dawnej Rzeczypospolitej i obecnie - praktyka i prawo', Rocznik Polskiego Towarzystwa Heraldycznego, 8 (19), 2008, pp. 115-32. 
Grześkowiak-Krwawicz, Anna, Regina libertas: Wolność w polskiej myśli politycznej XVIII wieku, Gdańsk: Słowo/Obraz Terytoria, 2006.

Jedlicki, Jerzy, Klejnot i bariery społeczne: Przeobrażenia szlachectwa polskiego w schytkowym okresie feudalizmu, Warsaw: Państwowe Wydawnictwo Naukowe, 1968. Jedlicki, Jerzy, 'Szlachta', in Przemiany społeczne w Królestwie Polskim 1815-1864, ed. Witold Kula and Janina Leskiewiczowa, Wrocław: Zakład Narodowy im. Ossolińskich, 1979, pp. 27-56.

Kaczmarczyk, Zdzisław, 'Kasztelanowie konarscy: Studium z historii urzędów ziemskich i nadwornych', CPH, 2, 1949, pp. 1-23.

Konarski, Stanisław, 'Rostworowski Janusz (1811-1891)', in PSB, vol. 32, Wrocław, 1989.

Konarski, Szymon, Armorial de la noblesse polonaise titrée, Paris: by author, 1958.

Konarski, Szymon, O heraldyce i 'heraldycznym' snobizmie, 2nd eds, Warsaw: Adiutor, 1992.

Kosiński, Adam Amilkar, Przewodnik heraldyczny: monografie kilkudziesięciu znakomitszych rodzin, 5 vols, Cracow and Warsaw, 1877-85, vol. 1, 1877.

Kowalski, Mariusz, Księstwa Rzeczpospolitej: Państwo magnackie jako region polityczny, Warsaw: Instytut Geografii i Przestrzennego Zagospodarowania PAN im. Stanisława Leszczyckiego, 2013.

Kowecki, Jerzy, 'Rostworowski Andrzej h. Nałęcz (1745-1831)', in PSB, vol. 32, Wrocław, 1989.

Kula, Witold, 'Udział we władzy', in Przemiany społeczne w Królestwie Polskim 18151864, ed. idem and Janina Leskiewiczowa, Warsaw: Zakład Narodowy im. Ossolińskich, 1979, pp. 405-19.

Lelewel, Joachim, Panowanie króla polskiego Stanisława Augusta, Brussels: Jan Nepomucen Młodecki, 1847.

Lelewel, Joachim, Trzy konstitucje polskie 1791, 1807, 1815, Poznań: J.K. Żupański, 1861.

Lenczewski, Tomasz, Genealogie rodów utytułowanych w Polsce, vol. 1, Warsaw: Adiutor, 1996.

Lukowski, Jerzy, The European Nobility in the Eighteenth Century, Basingstoke: Palgrave Macmillan, 2003.

Lukowski, Jerzy, Liberty's Folly: The Polish-Lithuanian Commonwealth in the Eighteenth Century, 1697-1795, London: Routledge, 1991.

Lulewicz, Henryk, Andrzej Rachuba and Jolanta Sikorska-Kulesza, 'Wstęp', in Dzieje rodziny Ciechanowieckich herbu Dabrowa (XIV-XXI wiek), ed. Andrzej Rachuba, Warsaw: DiG, 2013.

Łojek, Jerzy, Potomkowie Szczęsnego: Dzieje fortuny Potockich z Tulczyna 1799-1921, Lublin: Wydawnictwo Lubelskie, 1981.

Mencel, Tadeusz, 'Magnateria polska w Galicji w polityce władz austriackich w latach 1795-1809', in Ziemiaństwo polskie 1795-1945, ed. Janina Leskiewiczowa, Warsaw: Państwowe Wydawnictwo Naukowe, 1985.

Michalski, Jerzy, 'Sejmiki poselskie 1788 roku', in idem, Studia historyczne z XVIII i XIX wieku, 2 vols, Warsaw: Stentor, 2007, vol. 1, pp. 217-84. 
Mikocka-Rachubowa, Katarzyna, Rzeźba włoska w Polsce około 1770-1830: Katalog, Warsaw: Instytut Sztuki PAN, 2016.

Niesiecki, Kacper, Herbarz polski, 10 vols, ed. Jan Nepomucen Bobrowicz, Leipzig: Breitkopf \& Hærtel, 1839-46, vol. 6, 1841.

Orman, Elżbieta, Tahańcza Poniatowskich: Z dziejów szlachty na Ukrainie w XIX wieku, Cracow: PAU, 2009.

Polska encyklopedia szlachecka, ed. S.J. Starykoń-Kasprzycki, 12 vols, Warsaw: Instytut Kultury Historycznej, 1935-38, vol. 10, 1938.

Prószyńska, Zuzanna, Zegary Stanisława Augusta, Warsaw: Zamek Królewski 'Arx Regia', 1994.

Rostworowska, Weronika, 'Pomnik Michała Bogorii Skotnickiego a nekropolia wawelska na przełomie XVIII i XIX wieku', in Wzgórze wawelskie w słowie i w obrazie: $z$ badań nad kultura wieku XIX, ed. Joanna Winiewicz-Wolska and Joanna Ziętkiewicz-Kotz, Cracow: Zamek Królewski na Wawelu - Państwowe Zbiory Sztuki, 2014, pp. 117-30.

Rostworowski, Emanuel, Popioły i korzenie: szkice historyczne i rodzinne, Cracow: Znak, 1985.

Rostworowski, Stanisław Jan, Monografia rodziny Rostworowskich: Lata 1386-2012, 2 vols, Warsaw: Rytm, 2013.

Rostworowski, Stanisław Jan, 'W kręgu arystokratów respektujących władzę cesarzy Wszech Rosji i królów Polski', Rocznik Mazowiecki, 18, 2006, pp. 182-203.

Stężyński Bandtkie, Kazimierz Władysław, Numismatyka krajowa, 2 vols, Warsaw: J. Glücksberg, 1839-40, vol. 1, 1839.

Tarczyński, Marek, Generalicja powstania listopadowego, 2nd edn, Warsaw: Wydawnictwo Ministerstwa Obrony Narodowej, 1988.

[Uruski, Seweryn], Notices sur les familles illustres et titrées de la Pologne, Paris: A. Franck, 1862.

Uruski, Seweryn, Rodzina: herbarz szlachty polskiej, ed. Aleksander Włodarski, 15 vols, Warsaw: Gebethner i Wolff, 1904-31, vol. 15, 1931.

Vushko, Iryna, The Politics of Cultural Retreat: Imperial Bureaucracy in Austrian Galicia, 1772-1867, New Haven, CT: Yale University Press, 2015.

Widacka, Hanna, 'Ikonografia króla Stanisława Augusta w grafice XVIII wieku', Rocznik Historii Sztuki, 15, 1985, pp. 163-220.

Witwicki, Stefan, 'O hrabiach u nas', in Wieczory pielgrzyma: rozmaitości moralne, literackie i polityczne, 2 vols, Leipzig: F.A. Brockhaus, 1866, vol. 2, pp. 139-56.

Wolff, Józef, Kniaziowie litewsko-ruscy od końca czternastego wieku, Warsaw: [n. pub.], 1895.

Wolski, Marian, The Potocki Family of the Pilawa Coat of Arms: A Study of Family History and Estates until the Early $17^{\text {th }}$ Century, Cracow: Towarzystwo Naukowe Societas Vistulana, 2018.

Zajączkowski, Andrzej, Szlachta polska: Kultura i struktura, Warsaw: Semper, 1993.

Zaroszyc, Dominik, 'Posłowie' in Szymon Konarski, o heraldyce i 'heraldycznym' snobizmie, 2nd eds, Warsaw: Adiutor, 1992, pp. 54-77. 
Zielińska, Teresa, Magnateria polska epoki saskiej: Funkcje urzędów i królewszczyzn w procesie przeobrażeń warstwy szlacheckiej, Wrocław: Zakład Narodowy im. Ossolińskich, 1977.

Zielińska, Teresa, Poczet polskich rodów arystokratycznych, Warsaw: WSiP, 1997.

Biography: Mikołaj Getka-Kenig - PhD, associate professor at the Institute for the History of Science, Polish Academy of Sciences, area of research: socio-cultural history of the long nineteenth century, elite history, political history of architecture and art, the politics of history in the nineteenth and twentieth centuries. 